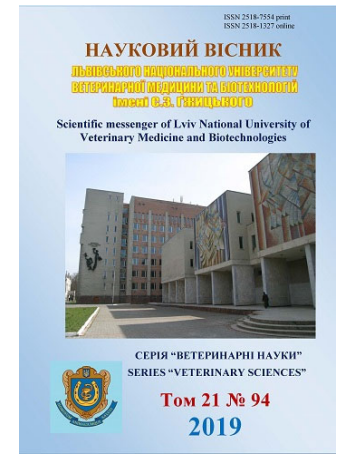

Науковий вісник Дьвівського національного університету ветеринарної медицини та біотехнологій імені С.З. Гжицького.

\author{
Серія: Ветеринарні науки
}

Scientific Messenger of Lviv National University of Veterinary Medicine and Biotechnologies. Series: Veterinary sciences

UDC 619:636.2

\title{
Protein synthesize function of bulls liver at experimental chronic cadmium toxicity
}

\author{
Y.Y. Lavryshyn, B.V. Gutyj \\ Stepan Gzhytskyi National University of Veterinary Medicine and Biotechnologies Lviv, Ukraine
}

Article info

Received 10.04.2019

Received in revised form 10.05.2019

Accepted 13.05.2019

Stepan Gzhytskyi National University of Veterinary Medicine and Biotechnologies Lviv, Pekarska Str., 50, Lviv, 79010, Ukraine. Tel.:+38-098-861-21-27 E-mail: iylia25071992@gmail.com
Lavryshyn, Y.Y., \& Gutyj, B.V. (2019). Protein synthesize function of bulls liver at experimental chronic cadmium toxicity. Scientific Messenger of Lviv National University of Veterinary Medicine and Biotechnologies. Series: Veterinary sciences, 21(94), 92-96. doi: 10.32718/nvlvet9417

The article presents the results of studies on the influence of cadmium load on the body of young cattle. The adverse effect of Cadmium on the liver causes a wide range of pathological changes at various levels of its organization. The purpose of the work was to investigate protein synthesize function on the liver of bulls for experimental chronic cadmium toxicity. The research was carried out on the basis of a farm at the village Ivanivtsi, Zhydachiv district of Lviv region, on 10 bulls of six months old, Ukrainian black-and-white milk breed, which were formed in 2 groups of 5 animals in each: control and experimental. Bulls of the control group were in the usual diet. Bulls of the experimental group were fed with forage with cadmium chloride at a dose of $0.04 \mathrm{mg} / \mathrm{kg}$ body weight of the animal. The research lasted for 30 days. Protein synthesize function of the liver was determined by the level of serum total protein and protein fractions. It was established that when feeding cows with feed of cadmium chloride in a dose of $0.04 \mathrm{mg} / \mathrm{kg}$ of body weight of an animal for 30 days in animals suppressed protein synthesize function of the liver, which manifests itself by lowering the total protein of blood. It reached the lowest level at the 20th day of the experiment, where, accordingly, it fluctuated within the limits of $61.9 \pm 1.14 \mathrm{~g} / \mathrm{l}$. Reducing the level of total protein in the blood of the bulls of the experimental group under cadmium loading was due to lowering the level of albumin. At day 20 of the experiment, the level of albumin in the blood of animals in the experimental group decreased by $16.5 \%$. On the background of general hypoproteinemia there is a significant imbalance between albumins and globulins in serum of diseased animals. It was established that the level of globulins increased in the blood of Bulls, which were under cadmium load. Increasing the level of globulins in blood serum of bulls reflects the intensity of inflammatory processes in their body for cadmium loading.

Key words: toxicology, cadmium, bulls, blood, proteins, albumins, globulins.

\section{Протеїнсинтезувальна функція печінки бугайців за експериментального хронічного кадмісвого токсикозу}

\author{
Ю.Ю. Лавришин, Б.В. Гутий
}

Львівський національний університет ветеринарної медицини та біотехнологій імені С.3. Гжиџького, м. Львів, Украӥна

У статті наведено результати досліджень впливу кадмієвого навантаження на організм молодняку великої рогатої худоби. Негативна дія Кадмію на печінку спричинює широкий спектр патологічних змін на різних рівнях ї̈ організації. Метою роботи було вивчити протеїнсинтезувальну функиію печінки бугайців за експериментального хронічного кадмієвого токсикозу. Дослідження проводились на базі фермерського господарства с. Іванівиі Жидачівського району Львівської області на 10 бугайцях иестимісячного віку, украӥнської чорно-рябої молочної породи, які були сформовані у 2 групи по 5 тварин у кожній: контрольну та дослідну. Бугайці контрольної групи знаходились на звичайному раціоні. Бугайцям дослідної групи згодовували з кормом хлорид кадмію у дозі 0,04 мг/кг маси тіла тварини. Дослід тривав упродовж 30-и діб. Протеїнсентизувальну функцію печінки визначали за рівнем у сироватиі крові загального протеїну та протеїнових фракиій. Встановлено, шэо при згодовуванні бугайцям з кормом кадмію хлори- 
ду у дозі 0,04 мг/кг маси тіла тварини протягом 30-ти діб у тварин пригнічується протеїнсинтезувальна функиія печінки, яка проявлясться зниженням загального протеїну крові. Найнижчого рівня він досяг на 20 добу досліду, де відповідно коливався у межах 61,9 \pm 1,14 г/л. Зниження рівня загального протеїну у крові бугайців дослідної групи за умов кадмієвого навантаження відбувалося за рахунок зниження рівня альбумінів. На 20 добу досліду рівень альбумінів у крові тварин дослідної групи знизився на 16,5\%. На тлі загальної гіпопротеінемії встановлено суттєву диспропориію між альбумінами $і$ глобулінами у сироватиі крові хворих тварин. Встановлено, шуо рівень глобулінів дещо зростав у крові бугайців, яким здійснювали кадмієве навантаження. Підвищення рівня глобулінів у сироватиі крові бугайців відображає інтенсивність запальних прочесів в їхньому організмі за кадмієвого навантаження.

Ключові слова: токсикологія, Кадмій, бугайці, кров, протеїни, альбуміни, глобуліни.

\section{Вступ}

Однією із основних причин, які суттєво впливають на фізіологічний стан організму, здоров'я людини і сільськогосподарських тварин, вважають екологічний стан довкілля. Проблема забруднення навколишнього середовища важкими металами, в тому числі Кадмієм, що є одним із наслідків інтенсифікації промислового й аграрного виробництва, нині набула особливої актуальності.

Результати багатьох експериментальних робіт вказують на те, що в організмі ссавців кадмій проявляє токсичний вплив на низку органів і систем, зокрема на серцево-судинну, статеву, видільну, дихальну, систему гемопоезу, опорно-рухову систему (Fregoneze et al., 1997; Rodríguez et al., 2001; Pavan Kumar \& Prasad, 2004; Uetani et al., 2005; Gutyj et al., 2015). До найнебезпечніших впливів належать канцерогенні та мутагенні ефекти цього елемента (Peng et al., 2015). Однак багато аспектів цієї проблеми ще й досі не з'ясовано.

Відомо, що за умов інтоксикації організму тварин сполуками кадмію виникає анемія, пригнічення функціонального стану імунної системи та інші розлади в процесах кровотворення (Honskyy et al., 2001; Hutyi, 2013; Gutyj et al., 2015; Gutyj et al., 2016; Lavryshyn et al., 2018).

Потрапляючи до організму, Кадмій взаємодіє на всіх рівнях: молекулярному, клітинному, органному, спричиняючи негативний вплив на метаболічні перетворення. За цього, для підтримання внутрішнього гомеостазу, включаються відповідні компенсаторні механізми.

Негативна дія Кадмію на печінку спричинює широкий спектр патологічних змін на різних рівнях іiі організації.

Тому метою роботи було вивчити протеїнсинтезувальну функцію печінки бугайців за експериментального хронічного кадмієвого токсикозу.

\section{Матеріал і методи досліджень}

Дослідження проводились на базі фермерського господарства с. Іванівці Жидачівського району Львівської області на 10 бугайцях шестимісячного віку, української чорно-рябої молочної породи, які були сформовані у 2 групи по 5 тварин у кожній: контрольну та дослідну. Бугайці контрольної групи знаходились на звичайному раціоні. Бугайцям дослідної групи згодовували 3 кормом хлорид кадмію у дозі 0,04 мг/кг маси тіла тварини.
Для проведення досліджень дотримувалися правил, обов'язкових з виконання зоотехнічних дослідів щодо підбору та утримання тварин-аналогів у групи, технології заготівлі, використання й обліку спожитих кормів. Раціон тварин був збалансований за поживними та мінеральними речовинами, які забезпечували їх потребу в основних елементах живлення.

Утримання, годівлю, догляд та усі маніпуляції 3 тваринами здійснювали згідно з Свропейською конвенцією "Про захист хребетних тварин, які використовуються для експериментальних і наукових цілей” (Страсбург, 1986 р.) і “Загальних етичних принципів експериментів на тваринах", ухвалених Першим Національним конгресом з біоетики (Київ, 2001). Експерименти проводили 3 дотриманням принципів гуманності, викладених у директиві Європейської Спільноти.

Дослід тривав упродовж 30-и діб. Кров для аналізу брали з яремної вени на 5-, 10-, 15-, 20-, і 30-ту добу досліду.

Протеїнсентизувальну функцію печінки визначали за рівнем у сироватці крові загального протеїну (біуретовою реакцією) і протеїнових фракцій (методом електрофорезу в поліакриламідному гелі) (Vlizlo, 2012).

Аналіз результатів досліджень проводили за допомогою пакету програм Statistica 6.0. Вірогідність різниць оцінювали за t-критерієм Стьюдента. Результати середніх значень вважали статистично вірогідними при * - $\mathrm{P}<0,05, * *-\mathrm{P}<0,001$ (ANOVA)

\section{Результати та їх обговорення}

Активність системи гемостазу прямо пов'язана із функціональним станом печінки. Гепатоцити $\epsilon$ основним місцем синтезу протеїнів системи зсідання крові та плазміногену - основного проензиму системи фібринолізу (Martyshuk et al., 2016; Gutyj et al., 2017).

Протеїни крові тварин, перебуваючи у тісному функціональному зв'язку з білками різних тканин, віддзеркалюють ті зміни, які настають у тканинах $\mathrm{i}$ органах організму за розладів у них процесів метаболізму, спричинених патологічними чинниками (Cherkashina \& Petrenko, 2006; Khariv et al., 2016; Hariv \& Gutyj, 2016). Саме тому рівень загального протеїну і його фракцій у крові бугайців за експериментального кадмієвого токсикозу, відображає протеїнсентизувальну функцію печінки та ефективність проведеного лікування.

Рівень загального протеїну у крові бугайців за хронічного кадмієвого токсикозу наведено у табли- 
ці 1. Встановлено, що на початку досліду рівень загального протеїну у крові бугайців контрольної та дослідної груп коливався у межах $67,8 \pm 1,12-67,1 \pm$ 1,13 г/л. При згодовуванні бугайцям хлориду кадмію у дозі 0,04 мг/кг маси тіла тварини, рівень загального протеїну у їх крові вірогідно знижувався вже починаючи 310 доби досліду, де відповідно з показниками контрольної групи тварин він знизився на 5,1\%. На 15 добу досліду рівень загального протеїну у крові бугайців дослідної групи знизився на 7\% відносно контролю. Найнижчого рівня він досяг на 20 добу досліду, де відповідно коливався у межах 61,9 1,14 г/л, тоді як у контрольної групи тварин даний показник становив 68,0 $\pm 1,13$ г/л.

Зниження рівня загального протеїну у крові бугайців дослідної групи за умов кадмієвого навантаження відбувалося за рахунок зниження рівня альбумінів.

\section{Таблиця 1}

Рівень загального протеїну у крові бугайців за хронічного кадмієвого токсикозу; $(\mathrm{M} \pm \mathrm{m}, \mathrm{n}=5)$

\begin{tabular}{lcc}
\hline \multirow{2}{*}{$\begin{array}{c}\text { Час дослідження } \\
\text { крові (доби) }\end{array}$} & \multicolumn{2}{c}{ Загальний протеїн (г/л) } \\
\cline { 2 - 3 } & \multicolumn{2}{c}{ Групи тварин } \\
\hline Вихідні величини & $67,8 \pm 1,12$ & Дослідна \\
П'ята доба & $68,2 \pm 1,10$ & $66,3 \pm 1,13$ \\
Десята доба & $68,1 \pm 1,15$ & $64,6 \pm 1,18^{*}$ \\
П'ятнадцята доба & $67,8 \pm 1,11$ & $63,0 \pm 1,12^{*}$ \\
Двадцята доба & $68,0 \pm 1,13$ & $61,9 \pm 1,14^{*}$ \\
Тридцята доба & $67,7 \pm 1,11$ & $63,8 \pm 1,16^{*}$ \\
\hline
\end{tabular}

Примітка: ступінь вірогідності порівняно 3 даними контрольної групи - $\mathrm{P}<0,05-*, \mathrm{P}<0,001$ - **

Як видно з даних таблиці 2 у крові бугайців дослідної групи рівень альбумінів на початку досліду коливався у межах 41,3 \pm 1,06 г/л. На 5 і 10 добу досліду рівень альбумінів у крові тварин дослідної групи знизився на 3,6 і 8,7\% відносно контрольної групи тварин. У подальшому рівень альбумінів у крові бугайців, яким здійснювали кадмієве навантаження, знизився до $36,7 \pm 1,43$ г/л. Найнижчим рівень альбумінів у крові тварин дослідної групи був на 20 добу досліду, де порівняно з контрольною групою він знизився на 16,5\% відповідно.

Таблиця 2

Рівень альбумінів у крові бугайців за хронічного кадмієвого токсикозу; ( $\mathrm{M} \pm \mathrm{m}, \mathrm{n}=5)$

\begin{tabular}{lcc}
\hline \multirow{2}{*}{\begin{tabular}{c} 
Час дослідження крові \\
\cline { 2 - 3 }
\end{tabular}} & \multicolumn{2}{c}{ Альбуміни (г/л) } \\
\cline { 2 - 3 } & Контрольна & Дослідна \\
\hline Вихідні величини & $41,5 \pm 1,20$ & $41,3 \pm 1,06$ \\
П'ята доба & $41,4 \pm 1,13$ & $39,9 \pm 2,02$ \\
Десята доба & $41,2 \pm 0,91$ & $37,6 \pm 1,61^{*}$ \\
П'ятнадцята доба & $41,5 \pm 1,23$ & $36,7 \pm 1,43^{*}$ \\
Двадцята доба & $41,3 \pm 1,05$ & $34,5 \pm 1,35^{*}$ \\
Тридцята доба & $41,4 \pm 1,01$ & $36,4 \pm 1,25^{*}$ \\
\hline
\end{tabular}

Примітка: ступінь вірогідності порівняно 3 даними контрольної групи - $\mathrm{P}<0,05-*, \mathrm{P}<0,001-* *$
На тлі загальної гіпопротеінемії встановлено суттєву диспропорцію між альбумінами і глобулінами у сироватці крові хворих тварин. Встановлено, що рівень глобулінів дещо зростав у крові бугайців, яким здійснювали кадмієве навантаження. Найвищого рівня він досягав на 20 і 30 доби досліду, де відповідно коливався у межах 27,4 $\pm 1,15-27,4 \pm 1,06$ г/л, тоді як у контролньої групи тварин даний показник становив $26,7 \pm 0,76$ і $26,3 \pm 0,60$ г/л.

\section{Таблиця 3}

Рівень глобулінів у крові бугайців за хронічного кадмієвого токсикозу; $(\mathrm{M} \pm \mathrm{m}, \mathrm{n}=5)$

\begin{tabular}{lcc}
\hline \multirow{2}{*}{\begin{tabular}{c} 
Час дослідження крові \\
\cline { 2 - 3 } \multicolumn{1}{c}{ (доби) }
\end{tabular}} & \multicolumn{2}{c}{ Глобуліни (г/л) } \\
\cline { 2 - 3 } & Контрольна тварин & Дослідна \\
\hline Вихідні величини & $26,3 \pm 0,60$ & $25,8 \pm 1,00$ \\
П'ята доба & $26,8 \pm 0,87$ & $26,4 \pm 0,98$ \\
Десята доба & $26,9 \pm 0,95$ & $27,0 \pm 1,03$ \\
П’ятнадцята доба & $26,3 \pm 0,99$ & $26,3 \pm 0,50$ \\
Двадцята доба & $26,7 \pm 0,76$ & $27,4 \pm 1,15$ \\
Тридцята доба & $26,3 \pm 0,60$ & $27,4 \pm 1,06$ \\
\hline
\end{tabular}

Примітка: ступінь вірогідності порівняно 3 даними контрольної групи - $\mathrm{P}<0,05-*, \mathrm{P}<0,001-* *$

Підвищення рівня глобулінів у сироватці крові бугайців відображає інтенсивність запальних процесів в їхньому організмі за кадмієвого навантаження.

Пригнічення стану печінки за кадмієвого навантаження відбувалося також через розвиток у дослідної групи тварин оксидаційного стресу.

\section{Висновки}

При згодовуванні бугайцям з кормом кадмію хлориду у дозі 0,04 мг/кг маси тіла тварини протягом 30ти діб у тварин пригнічується протеїнсинтезувальна функція печінки, яка проявляється зниженням загального протеїну крові, зниженням рівня альбумінів та збільшенням рівня глобулінів.

Перспективи подальших досліджень. У подальшому плануємо дослідити функціональний стан печінки бугайців за експериментального хронічного кадмієвого токсикозу.

\section{References}

Ali, M.M., Murthy, R.C., \& Chandra, S.V. (1986). Developmental and longterm neurobehavioral toxicity of low-level in utero $\mathrm{Cd}$ exposure in rats. Neurobehavioral Toxicology and Teratology, 8(5), 463-468. https://www.ncbi.nlm.nih.gov/pubmed/3785508.

Cherkashina, D.V., \& Petrenko, A.Y. (2006). Hepatoprotective effect of fetal tissue cytosol and its thermostable fraction in rats with carbon tetrachloride-induced hepatitis. B. Exp. Biol. Med., 141(4), 544-547. doi: 10.1007/s10517-006-0216-y.

Fregoneze, J.B., Marinho, C.A., Soares, T., Castro, L., Sarmento, C., Cunha, M., Gonzalez, V., Oliveira, P., Nascimento, T., Luz, C.P., Santana, Jr. P., De- 
Oliveira, I.R., \& e-Castro-e-Silva, E. (1997). Lead $(\mathrm{Pb} 2+)$ and cadmium $(\mathrm{Cd} 2+)$ inhibit the dipsogenic action of central beta-adrenergic stimulation by isoproterenol. Brazilian Journal of Medical and Biological Research, 30(3), 419-423. doi: 10.1590/S0100879X1997000300018.

Gutyj, B., Grymak, Y., Drach, M., Bilyk, O., Matsjuk, O., Magrelo, N., Zmiya, M., \& Katsaraba, O. (2017). The impact of endogenous intoxication on biochemical indicators of blood of pregnant cows. Regulatory Mechanisms in Biosystems, 8(3), 438-443. doi: 10.15421/021768.

Gutyj, B., Hufriy, D., Binkevych, V., Vischur, V., Binkevych, O., \& Kurlyak, I. (2015). The changes of biochemical and morphological indices of rats' blood under chronic cadmium toxicosis. Scientific Messenger of LNU of Veterinary Medicine and Biotechnologies, 17(3), 120-123. Retrieved from https://nvlvet.com.ua/index.php/journal/article/view/5 31.

Gutyj, B.V., Gufrij, D., Binkevych, V., Binkevych, O., Kurlyak, I., \& Sobolta, A. (2015). Influence of Mevesel \& E-selenium on level of intermediate and final products of lipid peroxidation in bulls' blood after cadmium loading. Scientific Messenger of LNU of Veterinary Medicine and Biotechnologies, 17(1), 190-194. Retrieved from https://nvlvet.com.ua/ index.php/journal/article/view/292.

Gutyj, B.V., Binkevych, V., \& Binkevych, O. (2016). Hematological changes of rats after cadmium toxicosis. Scientific Messenger of LNU of Veterinary Medicine and Biotechnologies, 18(1), 165-167. Retrieved from https://nvlvet.com.ua/index.php/ journal/article/view/110.

Gutyj, B.V., Murs'ka, S.D., Gufrij, D.F., Hariv, I.I., Levkivs'ka, N.D., Nazaruk, N.V., Gajdjuk, M.B., Pryjma, O.B., Bilyk, O.Ja., \& Guta, Z.A. (2016). Influence of cadmium loading on the state of the antioxidant system in the organism of bulls. Visnyk of Dnipropetrovsk University. Biology, ecology, 24(1), 96-102. doi: $10.15421 / 011611$

Gutyj, B., Martyshchuk, T., Bushueva, I., Semeniv, B., Parchenko, V., Kaplaushenko, A., Magrelo, N., Hirkovyy, A., Musiy, L., \& Murska, S. (2017). Morphological and biochemical indicators of blood of rats poisoned by carbon tetrachloride and subject to action of liposomal preparation. Regulatory Mechanisms in Biosystems, 8(2), 304-309. doi: 10.15421/021748.

Gutyj, B., Grymak, Y., Drach, M., Bilyk, O., Matsjuk, O., Magrelo, N., Zmiya, M., \& Katsaraba, O. (2017). The impact of endogenous intoxication on biochemical indicators of blood of pregnant cows. Regulatory Mechanisms in Biosystems, 8(3), 438-443. doi: $10.15421 / 021768$.

Hariv, M.I., \& Gutyj, B.V. (2016). Vplyv liposomalnoho preparatu Butaintervit na proteinsyntezuvalnu funktsiiu pechinky shchuriv za otruiennia tetrakhlormetanom [Influence of the liposomal preparation Butaintervite on protein synthesis function in the livers of rats under the influence of carbon tetrachloride poisoning].
Visnyk of Dnipropetrovsk University. Biology, medicine, 7(2), 123-126. doi: 10.15421/021622 (in Ukrainian).

Honskyy, Ya.I., Yastremskaya, S.O., \& Boychuk, B.R. (2001). Vikovi osoblyvostsi porushennya peroksydnoho okyslennya lipidiv i aktyvnosti enerhozabezpechuvalnyh fermentiv pry kadmiyeviy intoksykatsiyi [Age features breach of lipid peroxidation and activity of enzymes in utility cadmium intoxication] Medichna chimiya - Medical Chemistry, 3(1), 16-19 (in Ukrainian).

Hutyi, B.V. (2013). Riven pokaznykiv nefermentnoi systemy antyoksydantnoho zakhystu orhanizmu bychkiv za umov kadmiievoho navantazhennia. Naukovyi visnyk Lvivskoho natsionalnoho universytetu veterynarnoi medytsyny ta biotekhnolohii im. Gzhytskoho, 15, 1(4), 40-45. Rezhym dostupu: http://nbuv.gov.ua/UJRN/nvlnu $2013 \quad 15 \quad 1(4) \quad 10$ (in Ukrainian).

Hutyi, B.V. (2013). Vmist vitaminiv A i E u krovi bychkiv za umov kadmiievoi intoksykatsii. Visnyk Sumskoho natsionalnoho ahrarnoho universytetu. Seriia: Veterynarna medytsyna, 2, 31-33. Rezhym dostupu: http://nbuv.gov.ua/UJRN/Vsna_vet_2013_2_10 (in Ukrainian).

Hutyi, B.V. (2013). Vplyv E-selenu na aktyvnist hlutationovoi systemy antyoksydantnoho zakhystu orhanizmu buhaitsiv pry kadmiievomu navantazhenni. Visnyk Sumskoho natsionalnoho ahrarnoho universytetu. Seriia: Veterynarna medytsyna. 9, 7073. Rezhym dostupu: http://nbuv.gov.ua/UJRN/ Vsna vet 2013922 (in Ukrainian).

Hutyi, B.V. (2013). Vplyv E-selenu na vmist vitaminiv A i E u krovi bychkiv za umov kadmiievoi intoksykatsii. Naukovyi visnyk Lvivskoho natsionalnoho universytetu veterynarnoi medytsyny ta biotekhnolohii im. Gzhytskoho, 15, 3(3), 311-314. Rezhym dostupu: http://nbuv.gov.ua/UJRN/nvlnu $2013 \quad 15 \quad 3(3) \quad 55$ (in Ukrainian).

Hutyi, B.V. (2013). Vplyv khlorydu kadmiiu u riznykh dozakh na aktyvnist aminotransferaz syrovatky krovi buhaitsiv. Naukovyi visnyk Lvivskoho natsionalnoho universytetu veterynarnoi medytsyny ta biotekhnolohii im. Gzhytskoho, 15, 1(1), 49-52. Rezhym dostupu: http://nbuv.gov.ua/UJRN/nvlnu $2013 \quad 15 \quad 1(1)$ (in Ukrainian).

Hutyi, B.V. (2013). Vplyv khlorydu kadmiiu u toksychnykh dozakh na hlutationovu systemu antyoksydantnoho zakhystu orhanizmu bychkiv. Veterynarna biotekhnolohiia, 22, 112-116. Rezhym dostupu: http://nbuv.gov.ua/UJRN/vbtb_2013 22 23 (in Ukrainian).

Hutyi, B.V. (2013). Vplyv Meveselu na pokaznyky neenzymnoi systemy antyoksydantnoho zakhystu orhanizmu buhaitsiv za umov kadmiievoho navantazhennia. Biolohiia tvaryn, 15(3), 16-21. Rezhym dostupu: http://nbuv.gov.ua/UJRN/bitv_2013_15 3 4 (in Ukrainian).

Hutyi, B.V. (2013). Vplyv meveselu na vmist vitaminiv A i E u krovi bychkiv za umov kadmiievoi intoksykatsii. 
Naukovyi visnyk Lvivskoho natsionalnoho universytetu veterynarnoi medytsyny ta biotekhnolohii im. Gzhytskoho, 15, 3(1), 78-82. Rezhym dostupu: http://nbuv.gov.ua/UJRN/nvlnu_2013_15_3(1)_18 (in Ukrainian).

Hutyi, B.V. (2013). Vplyv meveselu ta E-selenu na riven pokaznykiv ne fermentnoi systemy antyoksydantnoho zakhystu orhanizmu buhaitsiv pry kadmiievomu navantazhenni. Veterynarna medytsyna, 97, 419-421. Rezhym dostupu: http://nbuv.gov.ua/UJRN/ vetmed_2013_97_172 (in Ukrainian).

Khariv, M., Gutyj, B., Butsyak, V., \& Khariv, I. (2016). Hematological indices of rat organisms under conditions of oxidative stress and liposomal preparation action. Biological Bulletin of Bogdan Chmelnitskiy Melitopol State Pedagogical University. 6 (1), 276-289. doi: 10.15421/201615.

Lavryshyn, Y.Y., Gutyj, B.V., Palyadichuk, O.R., \& Vishchur, V.Y. (2018). Morphological blood indices of bulls in experimental chronic cadmium toxicosis. Scientific Messenger of Lviv National University of Veterinary Medicine and Biotechnologies, 20(88), 108-114. doi: 10.32718/nvlvet8820.

Liu, J., Qian, S.Y., Guo, Q., Jiang, J., Waalkes, M.P., Mason, R.P., \& Kadiiska, M.B. (2008). Cadmium generates reactive oxygen- and carbon-centered radicalspecies in rats: Insights from in vivo spintrappingstudies. Free Radic Biol Med., 45(4), 475481. doi: 10.1016/j.freeradbiomed.2008.04.041.

Lu, J., Jin, T., Nordberg, G., \& Nordberg, M. (2005). Metallothionein gene expression in peripheral lymphocytes and renal dysfunction in a population environmentally exposed to cadmium. Toxicol Appl Pharmacol 206(2), 150-156. doi: 10.1016/j.taap.2004.12.015.

Martyshuk, T.V., Gutyj, B.V., \& Vishchur, O.I. (2016). Level of lipid peroxidation products in the blood of rats under the influence of oxidative stress and under the action of liposomal preparation of " $\mathrm{Bu}$ taselmevit', Biological Bulletin of Bogdan Chmelnitskiy Melitopol State Pedagogical University, 6 (2), 22-27. doi: 10.15421/201631.

Nazaruk, N., Gutyj, B.V., \& Hufriy, D. (2015). Influence of metifen and vitamix se on the activity of aminotransferases of bulls blood serum at cadmium nitrate loading. Scientific Messenger of LNU of Veterinary Medicine and Biotechnologies, 17(1), 121126. Retrieved from https://nvlvet.com.ua/index.php/ journal/article/view/231.

Pavan Kumar, G., \& Prasad, M.N.V. (2004). CadmiumInducible Proteins in Ceratophyllum demersum L. (a Fresh Water Macrophyte): Toxicity Bioassays and Relevance to Cadmium Detoxification. Bulletin of Environmental Contamination and Toxicology, 73(1), 174-181. doi: 10.1007/s00128-004-0410-4.

Peng, L., Wang, X., Huo, X., Xu, X., Lin, K., Zhang, J., Huang, Y., \& Wu, K. (2015). Blood cadmium burden and the risk of nasopharyngeal carcinoma: a casecontrol study in Chinese Chaoshan population. Environmental Science and Pollution Research, 22(16), 12323-12331. doi: 10.1007/s11356-015-4533-4.

Rodríguez, E.M., Bigi, R., Medesani, D.A., Stella, V.S., Greco, L.S.L., Moreno, P.A.R., Monserrat, J.M., Pellerano, G.N., \& Ansaldo, M. (2001). Acute and chronic effects of cadmium on blood homeostasis of an estuarine crab, Chasmagnathus granulata, and the modifying effect of salinity. Brazilian Journal of Medical and Biological Research. 34(4), 509-518. https://www.ncbi.nlm.nih.gov/pubmed/11285463.

Salvatori, F., Talassi, CB, Salzgeber, S.A., Sipinosa, H.S., \& Bernardi, M.M. (2004). Embryotoxic and long-term effects of cadmium exposure during embryogenesis in rats. Neurotoxicology and Teratology, 26(5), 673680. doi: 10.1016/j.ntt.2004.05.001.

Uetani, M., Kobayashi, E., Suwazono, Y., Okubo, Y., Honda, R., Kido, T., \& Nogawa, K. (2005). Selenium, Cadmium, Zinc, Copper, and Iron Concentrations in Heart and Aorta of Patients Exposed to Environmental Cadmium. Bulletin of Environmental Contamination and Toxicology, 75(2), 246-250. doi: 10.1007/s00128-005-0744-6.

Vlizlo, V.V. (2012). Laboratorni metody doslidzhen u biolohiyi, tvarynnytstvi ta veterynarniy medytsyni [Laboratory methods of investigation in biology, stock-breeding and veterinary]. Spolom, Lviv (in Ukrainian). 